\title{
Water deficit in cotton plant originated from seeds treated with growth regulator ${ }^{1}$
}

\author{
Alexandre Cunha de Barcellos Ferreira ${ }^{2}$, Fernando Mendes Lamas ${ }^{3}$, \\ Giovani Greigh de Brito ${ }^{4}$, Ana Luiza Dias Coelho Borin ${ }^{2}$
}

\section{RESUMO}

Déficit hídrico em algodoeiro proveniente de sementes tratadas com regulador de crescimento

O cloreto de mepiquat $(\mathrm{CM})$ é usado para controlar o crescimento do algodoeiro. Alterações no crescimento da parte aérea podem influenciar no desenvolvimento das raízes e, por consequência, interferir na sensibilidade do algodoeiro ao déficit hídrico. Este trabalho objetivou avaliar o efeito do déficit hídrico, em estádios fenológicos iniciais de algodoeiro originado de sementes tratadas com doses de CM, sobre o crescimento de raízes e parte aérea. Dois experimentos foram realizados em casa-devegetação, em Santa Helena de Goiás (GO), sendo conduzidos em blocos casualizados, em esquema fatorial $4 \times 4$ : quatro doses de regulador de crescimento $(0 \mathrm{~g}, 2 \mathrm{~g}, 4 \mathrm{~g}$ e $8 \mathrm{~g}$ do ingrediente ativo de $\mathrm{CM}$ por kg de semente) e quatro situações de déficit hídrico (sem déficit hídrico e déficit hídrico inicial em três fases vegetativas: V1, V3 e V5), com quatro repetições. A matéria seca da parte aérea e das raízes e a altura dos algodoeiros foram reduzidas com o aumento nas doses de CM. O déficit hídrico entre V1 e V5 reduziu a massa de matéria seca da parte aérea e das raízes. O déficit hídrico também aumentou o efeito inibidor do CM aplicado via semente sobre a produção de matéria seca de raízes e da parte aérea do algodoeiro.

PALAVRAS-CHAVE: Gossypium hirsutum L. r. latifolium; cloreto de mepiquat; estresse hídrico.

\section{INTRODUCTION}

The favorable nutrition and climatic conditions (sunlight, water and temperature) normally results in excessive vegetative growth in cotton cultivars, which can enhance pests and diseases control problems and boll rot, as well as affect mechanical harvest and favor fruit abscission (Oosterhuis 2001).

Growth regulators are efficient in controlling cotton plant growth, resulting in more compact plants and increasing the first-position fruit retention (Reddy



Mepiquat chloride (MC) is widely used for controlling cotton plant growth. Shoot growth modifications may affect root growth and, consequently, interfere with the cotton sensitivity to water deficit. This study aimed at evaluating the water deficit effects, in initial phenological stages of cotton plants from seeds treated with MC doses, on shoot and root growth. Two experiments were carried out in a greenhouse, in Santa Helena de Goiás, Goiás State, Brazil, in a randomized blocks design, in a $4 \times 4$ factorial scheme: four growth regulator doses $(0 \mathrm{~g}, 2 \mathrm{~g}, 4 \mathrm{~g}$ and $8 \mathrm{~g}$ of active ingredient of $\mathrm{MC}$ per $\mathrm{kg}$ of seed) and four water stress conditions (without water deficit and initial water deficit in three vegetative growth stages: V1, V3 and V5), with four replications. Shoot and root dry matter, as well as cotton plant height, decreased with the increase of MC doses. The water deficit between V1 and V5 reduced shoot and root dry matter. The water deficit also increased the inhibitory effect of MC applied via seeds on cotton plants shoot and root dry matter.

KEY-WORDS: Gossypium hirsutum L. r. latifolium; mepiquat chloride; hidric stress.

et al. 1992a, Lamas 2001, Stewart et al. 2001, Nichols et al. 2003).

Mepiquat chloride (MC) is a growth regulator that reduces the gibberellic acid concentration in plants and, consequently, growth and cell elongation (Rademacher 2000, Stewart et al. 2001, Taiz \& Zeiger 2010). On the other hand, MC can modify root development patterns, if considered its effects on hormones balance, what could reduce the root growth ratio, making cotton plants more susceptible to water deficit, particularly in their initial growth stage. Thus,

1. Article received in Feb./2013 and accepted for publication in Nov./2013 (Registration number: PAT 22511).

2. Empresa Brasileira de Pesquisa Agropecuária (Embrapa Algodão), Santo Antônio de Goiás, GO, Brasil. E-mails: alexandre-cunha.ferreira@embrapa.br, ana.borin@embrapa.br.

3. Empresa Brasileira de Pesquisa Agropecuária (Embrapa Agropecuária Oeste), Dourados, MS, Brasil. E-mail: fernando.lamas@embrapa.br.

4. Empresa Brasileira de Pesquisa Agropecuária (Embrapa Algodão), Pelotas, RS, Brasil. E-mail: giovani.brito@embrapa.br. 
it is important to investigate the effects of $\mathrm{MC}$ on cotton plants exposed to water deficit conditions.

Some reports have shown that cotton seeds treated with MC have resulted in lower plant growth, since its emergence stage (Nagashima et al. 2005). Iqbal et al. (2005) observed that seeds treated with high MC doses may increase the number of days to the first true leaves emergence. Yeats et al. (2005) concluded that growth reduction was more pronounced with increasing $\mathrm{MC}$ doses.

Shoot growth modification may influence the root growth and development, and thus interfere with the cotton sensitivity to water deficit. Although the strategy for cotton response to water deficit involves osmotic adjustment capacity, resilience of its photochemical apparatus and stomatal conductance regulation, the modulation of shoot and root growth and development can also determine their responses to water deficit, especially in crops under the Brazilian Savannah climate and soil (Brito et al. 2011, 2013). In this biome, which is dominated by Oxisols with high water retention capacity, the adoption of a cotton crop system that provides root growth may favor the most effective use of available water in subsurface layers, and thereby reduce water deficit stress during dry seasons, which historically occurs after sowing and can affect the early cotton development stages.

This study aimed at evaluating the influence of water deficit in the initial phenological stages of cotton plants from seeds treated with mepiquat chloride doses.

\section{MATERIAL AND METHODS}

Two experiments were carried out in a greenhouse, in Santa Helena de Goiás, Goiás State, Brazil (17 $50^{\circ} \mathrm{S}, 50^{\circ} 34^{\prime} \mathrm{W}$ and $596 \mathrm{~m}$ of altitude), in 2009.

The first experiment was installed on June 10th and harvested on August 14th, 58 days after the cotton emergence (DAE), while the second one was carried out from September 30th to November 20th, being harvested at 45 DAE. Maximum and minimum temperatures are presented in Figure 1.

The experiments were conducted in a randomized blocks design, with four replications. Treatments for both experiments were arranged in a $4 \times 4$ factorial scheme, with four MC doses $(0 \mathrm{~g}, 2 \mathrm{~g}$, $4 \mathrm{~g}$ and $8 \mathrm{~g}$ of active ingredient - a.i. per $\mathrm{kg}$ of seed), and four water stress conditions (without water deficit and water deficit in three vegetative growth stages: V1, V3 and V5, respectively with the 1st, 3rd and 5th true leaves unfolded) (Marur \& Ruano 2001). The experimental unit consisted of three plants per pot.

BRS 269-Buriti cultivar seeds, characterized by tall plants, were sown in both experiments, after being treated with carboxin ( $1 \mathrm{~g}$ of a.i. per $\mathrm{kg}$ of seed) plus thiram ( $1 \mathrm{~g}$ of a.i. per $\mathrm{kg}$ of seed), then thiametoxan (2 $\mathrm{g}$ of a.i. per $\mathrm{kg}$ of seed) and, finally, MC doses.

One kilogram of seeds was treated with a MC commercial solution ( $250 \mathrm{~g}$ of a.i. per L), at the following doses: control (no MC, $32 \mathrm{~mL}$ of water); $2 \mathrm{~g}$ of a.i. ( $8 \mathrm{~mL}$ of MC commercial solution plus $24 \mathrm{~mL}$ of water); $4 \mathrm{~g}$ of a.i. (16 $\mathrm{mL}$ of $\mathrm{MC}$ commercial solution plus $16 \mathrm{~mL}$ of water); and $8 \mathrm{~g}$ of a.i. (32 $\mathrm{mL}$ of $\mathrm{MC}$ commercial solution). After the $\mathrm{MC}$ application, each lot of treated seeds was air dried at room temperature, for 16 hours, and then sowed.

Plastic pots (12 L) were filled with soil, cattle manure and sand, respectively in the volume ratio of $3: 1: 1$. The soil analysis showed the following characteristics: sand $=23 \%$, silt $=17 \%$, clay $=60 \%$, $\mathrm{pH}\left(\mathrm{CaCl}_{2}\right)=5.9, \mathrm{Ca}^{2+}=3.10 \mathrm{cmol}_{\mathrm{c}} \mathrm{dm}^{-3}, \mathrm{Mg}^{2+}=$ $0.72 \mathrm{cmol}_{\mathrm{c}} \mathrm{dm}^{-3}, \mathrm{~K}=71 \mathrm{mg} \mathrm{dm}^{-3}, \mathrm{Al}^{3+}=0.0 \mathrm{cmol}_{\mathrm{c}} \mathrm{dm}^{-3}$, $\mathrm{H}+\mathrm{Al}=2.50 \mathrm{cmol}_{\mathrm{c}} \mathrm{dm}^{-3}, \mathrm{P}($ Mehlich 1$)=6 \mathrm{mg} \mathrm{dm}^{-3}$, $\mathrm{S}=9 \mathrm{mg} \mathrm{dm}^{-3}, \mathrm{OM}^{\mathrm{c}}=28 \mathrm{~g} \mathrm{dm}^{-3}, \mathrm{CEC}=6.5 \mathrm{cmol}^{\mathrm{d}} \mathrm{dm}^{-3}$ and $\mathrm{V}=62 \%$. The soil was enriched with $0.75 \mathrm{~g} \mathrm{~kg}^{-1}$ of NPK fertilizer (4-30-16). Field capacity was determined by water retention curves from the dried and sieved substrate (Embrapa 1997).

Soil moisture was maintained at $60 \%$ of the water holding capacity, by daily weighing the pots, for subsequent replacement of evapotranspired water. Water deficit treatments were applied for seven days, starting in each phenological stage of the study, restarting the irrigation after the end of each stress treatment, before the cotton plant reached a permanent wilting point.

Cotton plant height (from substrate surface to plant top) was determined at 42, 45, 48, 51, 54 and 58 DAE (experiment 1) and at 29, 32, 35, 42 and 45 DAE (experiment 2). Experiments 1 and 2 were finished at $58 \mathrm{DAE}$ and $45 \mathrm{DAE}$, respectively, when cotton phenological stages were B2 (2nd square) to B3 (3rd square) (Marur \& Ruano 2001). Shoots and roots from each plot were collected and dried separately at $62^{\circ} \mathrm{C}$, in a thermo-ventilated oven, until constant weight. 

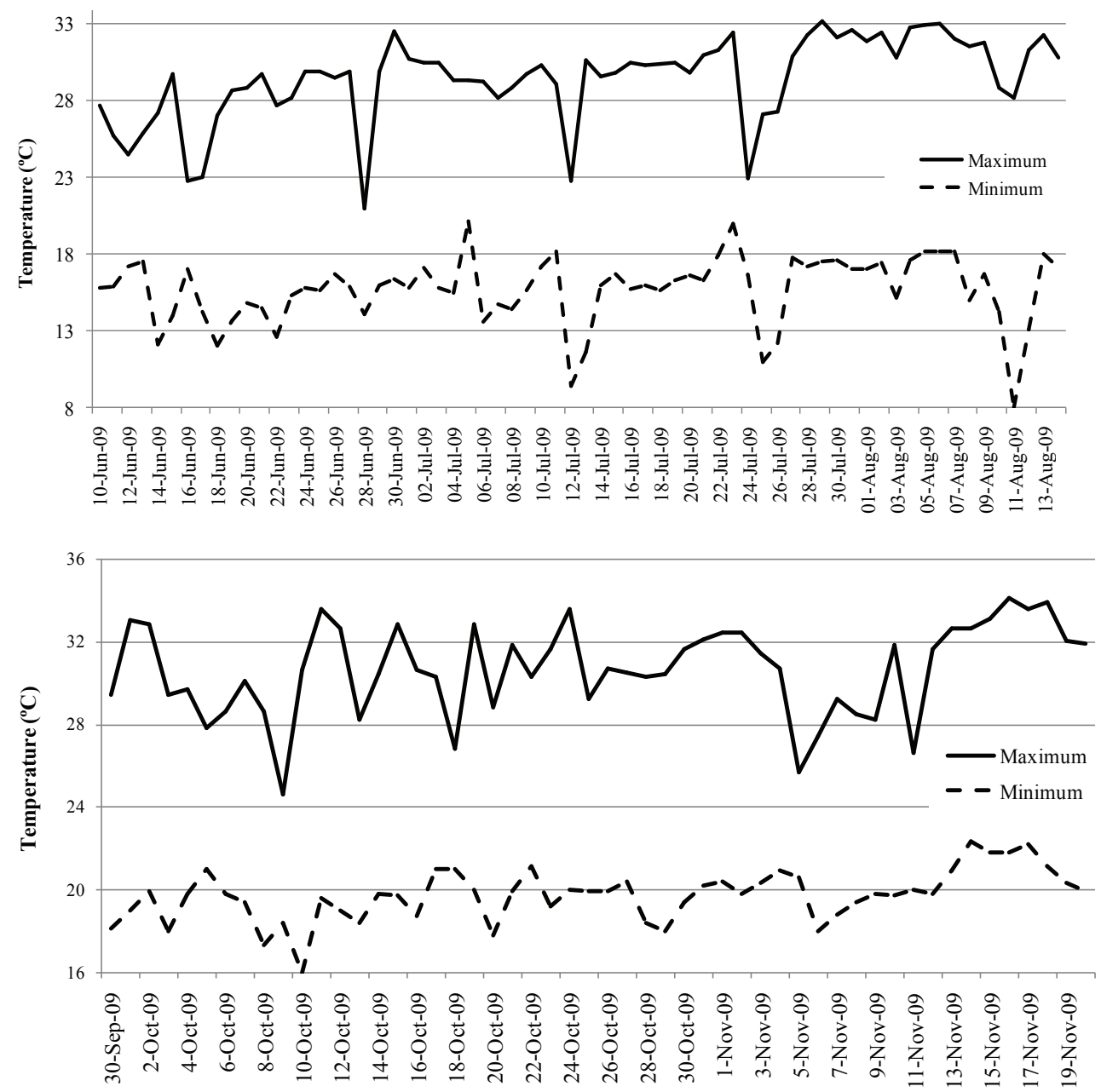

Figure 1. Maximum and minimum temperatures inside the greenhouse, for the experiment 1 (June 10th to August 14th) and experiment 2 (September 30th to November 20th) (Santa Helena de Goiás, GO, 2009).

Although treatments were similar, the statistical analysis of experimental data was carried out separately, due to the differences of temperature inside the greenhouse, which may have influenced the results during the period of conduction of the experiments and the evaluation time of cotton plants heights.

Data were subjected to analysis of variance (Anova) and the averages compared by using the Tukey's test $(\mathrm{p} \leq 0.05)$, for qualitative variable water stress. Regression analyses were performed to evaluate the influence of $\mathrm{MC}$ doses on root and shoot parameters.

\section{RESULTS AND DISCUSSION}

The statistical analysis of cotton plant height did not show a significant interaction between MC doses and water deficit stages. Since there was no interaction effect, the results for MC doses were shown across water deficit imposition phases.

In both experiments, MC doses applied through seed treatment significantly influenced cotton plant height, at different assessment times (Tables 1 and 2), except for the evaluation at $45 \mathrm{DAE}$, in the experiment 1 . Before 45 DAE, cotton plants were still under water deficit, when probably the influence of MC doses on plant height was not evident.

Cotton height decreased linearly by increasing the MC doses applied to seeds (Tables 1 and 2). Cotton growth control after seed treatment with MC was also observed by Nagashima et al. (2005, 2007), Yeats et al. (2005) and Lamas (2006). Yeats et al. (2005) also verified that the duration and extent of plant height reductions were greater as the MC concentration increased. Under field conditions, Nagashima et al. (2007) concluded that seeds soaked 
Table 1. Cotton plant height and shoot dry matter, according to the use of mepiquat chloride as a seed treatment - experiment 1 (Santa Helena de Goiás, GO, 2009).

\begin{tabular}{lllllll}
\hline \multirow{2}{*}{ Characteristic } & \multicolumn{4}{c}{ Mepiquat chloride $\left(\mathrm{g}\right.$ a.i. $\mathrm{kg}^{-1}$ of seed $)$} & & \multirow{2}{*}{ Regression equation / $\mathrm{R}^{2(1)}$} \\
\cline { 2 - 5 } & 0 & 2 & 4 & 8 & \\
\hline Height at 42 DAE $(\mathrm{cm})$ & 27.8 & 24.4 & 25.8 & 24.3 & $\hat{\mathrm{y}}=26.75-0.341 * \mathrm{x}\left(\mathrm{R}^{2}=0.49\right)$ \\
Height at 45 DAE $(\mathrm{cm})$ & 31.8 & 28.9 & 29.7 & 27.8 & $\mathrm{~ns}$ \\
Height at 48 DAE $(\mathrm{cm})$ & 35.2 & 31.9 & 33.4 & 29.9 & $\hat{\mathrm{y}}=34.60-0.565 * * \mathrm{x}\left(\mathrm{R}^{2}=0.74\right)$ \\
Height at 51 DAE $(\mathrm{cm})$ & 39.7 & 36.5 & 37.9 & 33.8 & $\hat{\mathrm{y}}=39.25-0.648 * * \mathrm{x}\left(\mathrm{R}^{2}=0.79\right)$ \\
Height at 54 DAE $(\mathrm{cm})$ & 43.6 & 40.4 & 41.9 & 36.6 & $\hat{\mathrm{y}}=43.37-0.782 * * \mathrm{x}\left(\mathrm{R}^{2}=0.82\right)$ \\
Height at 58 DAE $(\mathrm{cm})$ & 46.9 & 43.1 & 44.1 & 39.0 & $\hat{\mathrm{y}}=46.42-0.901 * * \mathrm{x}\left(\mathrm{R}^{2}=0.87\right)$ \\
Shoot dry matter $(\mathrm{g})$ & 31.07 & 22.79 & 23.53 & 21.61 & $\hat{\mathrm{y}}=30.24-3.144 * * \mathrm{x}+0.262 * * \mathrm{x}^{2}\left(\mathrm{R}^{2}=0.85\right)$ \\
\hline
\end{tabular}

DAE: days after emergence. $\mathrm{ns},{ }^{*}$ and ${ }^{* *}$ : non significant and significant at $5 \%$ and $1 \%$, respectively, by the $\mathrm{F}$ test. ${ }^{(1)}$ Coefficient of determination.

Table 2. Cotton plant height and root dry matter, according to the use of mepiquat chloride as a seed treatment - experiment 2 (Santa Helena de Goiás, GO, 2009).

\begin{tabular}{|c|c|c|c|c|c|}
\hline \multirow{2}{*}{ Characteristic } & \multicolumn{4}{|c|}{ Mepiquat chloride (g a.i. $\mathrm{kg}^{-1}$ of seed) } & \multirow{2}{*}{ Regression equation / $\mathrm{R}^{2(1)}$} \\
\hline & 0 & 2 & 4 & 8 & \\
\hline Height at 29 DAE $(\mathrm{cm})$ & 27.4 & 24.6 & 23.9 & 20.2 & $\hat{\mathrm{y}}=27.04-0.867 * * x\left(\mathrm{R}^{2}=0.97\right)$ \\
\hline Height at 32 DAE (cm) & 31.0 & 27.7 & 27.3 & 22.6 & $\hat{\mathrm{y}}=30.57-0.983^{* * x}\left(\mathrm{R}^{2}=0.96\right)$ \\
\hline Height at 35 DAE (cm) & 35.9 & 33.6 & 31.3 & 26.7 & $\hat{\mathrm{y}}=35.90-1.147 * * x\left(\mathrm{R}^{2}=0.96\right)$ \\
\hline Height at 42 DAE (cm) & 48.4 & 45.5 & 42.6 & 36.8 & $\hat{\mathrm{y}}=48.36-1.447 * * x\left(\mathrm{R}^{2}=0.94\right)$ \\
\hline Height at 45 DAE (cm) & 56.2 & 51.3 & 51.2 & 43.7 & $\hat{\mathrm{y}}=55.74-1.473^{* *} \mathrm{x}\left(\mathrm{R}^{2}=0.95\right)$ \\
\hline Root dry matter (g) & 9.28 & 8.48 & 7.65 & 6.23 & $\hat{\mathrm{y}}=9.24-0.38^{* *} \mathrm{x}\left(\mathrm{R}^{2}=0.99\right)$ \\
\hline
\end{tabular}

DAE: days after emergence. ${ }^{* *}$ Significant at $1 \%$, by the $\mathrm{F}$ test. ${ }^{(1)}$ Coefficient of determination.

in MC solutions affected plant height up to 31 DAE. However, these authors prepared solutions with MC concentrations of $0-7.5 \%(\mathrm{v} / \mathrm{v})$, and then $260 \mathrm{~g}$ of seeds were immersed in each solution, for 12 hours. Therefore, it is impracticable to know precisely the amount of MC effectively absorbed.

The lowest MC dose produced a faster growth resumption, in both experiments, when compared to high doses. According to Yeats et al. (2005), the MC effect on plant growth reduction was greater when the MC dose increased.

In the first experiment (fall and winter), the cotton plants growth was lower than in the second experiment (spring). The lowest temperatures in the first experiment resulted in a lower cotton plant height than in the experiment 2 (Tables 1 and 2), as also reported by Reddy et al. (1992b), Robertson et al. (2007) and Wells \& Stewart (2010).

Water deficit significantly influenced all the characteristics evaluated. Cotton plant height was lower when water deficit was imposed in the V1 and V5 growth stages than without water stress (Table 3 ). After 45 DAE, the lowest cotton plant height was observed in the treatment with water deficit in the
V5 growth stage, and plants did not recover the height until the end of the experiment. Hidric deficit in the V3 growth stage was less severe than in V1 and V5, for cotton plant height, and it did not differ significantly from the control.

In the second experiment, plant height was different for the control and treatments with water deficit at the V1 and V3 growth stages. However, after 35 DAE, it was similar for the control and water deficit at the V1 growth stage (Table 4). The cotton plant growth recovery and dry matter production, after re-irrigation, are dependent, at least in part, of water stress severity and growth stage (Brito et al. 2011). Pace et al. (1999) observed that cotton plants subjected to water deficit for 13 days, and then irrigated for 10 days, recovered their growth.

Cotton plant height differences, between 29 DAE and 32 DAE, divided by three days resulted in a daily growth rate of $0.33 \mathrm{~cm} \mathrm{day}^{-1}$, in $\mathrm{V} 3$, being this value the lowest one in experiment 2 (Table 4). Between $42 \mathrm{DAE}$ and $45 \mathrm{DAE}$, the growth rate was $2.7 \mathrm{~cm} \mathrm{day}^{-1}$, indicating that cotton plants recovered shoot growth during the period evaluated. In this same period, the daily growth rates in the treatments without 
Table 3. Cotton plant height and shoot dry matter, according to water deficit - experiment 1 (Santa Helena de Goiás, GO, 2009).

\begin{tabular}{cccccc}
\hline Characteristic & Without water deficit & Water deficit in V1 & Water deficit in V3 & Water deficit in V5 & LSD \\
\hline Height at 42 DAE $(\mathrm{cm})$ & $31.8 \mathrm{a}$ & $21.7 \mathrm{c}$ & $25.4 \mathrm{~b}$ & $23.3 \mathrm{bc}$ & 3.60 \\
Height at 45 DAE $(\mathrm{cm})$ & $35.7 \mathrm{a}$ & $27.1 \mathrm{bc}$ & $30.6 \mathrm{~b}$ & $24.8 \mathrm{c}$ & 3.97 \\
Height at 48 DAE $(\mathrm{cm})$ & $38.9 \mathrm{a}$ & $30.5 \mathrm{bc}$ & $34.4 \mathrm{~b}$ & $26.7 \mathrm{c}$ & 4.11 \\
Height at 51 DAE $(\mathrm{cm})$ & $42.6 \mathrm{a}$ & $35.8 \mathrm{~b}$ & $38.7 \mathrm{ab}$ & $30.8 \mathrm{c}$ & 4.20 \\
Height at 54 DAE $(\mathrm{cm})$ & $45.4 \mathrm{a}$ & $39.3 \mathrm{bc}$ & $42.2 \mathrm{ab}$ & $35.6 \mathrm{c}$ & 4.12 \\
Height at 58 DAE $(\mathrm{cm})$ & $47.9 \mathrm{a}$ & $41.7 \mathrm{bc}$ & $44.1 \mathrm{ab}$ & $39.4 \mathrm{c}$ & 4.15 \\
Shoot dry matter $(\mathrm{g})$ & $30.98 \mathrm{a}$ & $21.17 \mathrm{c}$ & $26.65 \mathrm{~b}$ & $20.19 \mathrm{c}$ & 4.16 \\
\hline
\end{tabular}

LSD: least significant difference. DAE: days after emergence. Values followed by the same letter, in the rows, are not significantly different, according to the Tukey's test $(\mathrm{p} \leq 0.05)$.

Table 4. Cotton plant height and root dry matter, according to water deficit - experiment 2 (Santa Helena de Goiás, GO, 2009).

\begin{tabular}{cccccc}
\hline Characteristic & Without water deficit & Water deficit in V1 & Water deficit in V3 & Water deficit in V5 & LSD \\
\hline Height at 29 DAE $(\mathrm{cm})$ & $26.0 \mathrm{a}$ & $21.7 \mathrm{~b}$ & $22.4 \mathrm{~b}$ & $26.0 \mathrm{a}$ & 2.2 \\
Height at 32 DAE $(\mathrm{cm})$ & $29.6 \mathrm{a}$ & $25.8 \mathrm{~b}$ & $23.4 \mathrm{~b}$ & $29.7 \mathrm{a}$ & 2.7 \\
Height at 35 DAE $(\mathrm{cm})$ & $35.3 \mathrm{a}$ & $32.2 \mathrm{a}$ & $27.2 \mathrm{~b}$ & $32.9 \mathrm{a}$ & 3.2 \\
Height at 42 DAE $(\mathrm{cm})$ & $47.9 \mathrm{a}$ & $46.5 \mathrm{a}$ & $38.5 \mathrm{~b}$ & $40.3 \mathrm{~b}$ & 3.9 \\
Height at 45 DAE $(\mathrm{cm})$ & $54.5 \mathrm{a}$ & $53.7 \mathrm{a}$ & $46.6 \mathrm{~b}$ & $47.6 \mathrm{~b}$ & 4.5 \\
Root dry matter $(\mathrm{g})$ & $10.90 \mathrm{a}$ & $7.33 \mathrm{~b}$ & $6.30 \mathrm{~b}$ & $6.94 \mathrm{~b}$ & 2.17 \\
\hline
\end{tabular}

LSD: least significant difference. DAE: days after emergence. Values followed by the same letter, in the rows, are not significantly different, according to the Tukey's test $(\mathrm{p} \leq 0.05)$.

water stress and stress in V1 and V5 were $2.2 \mathrm{~cm}^{\text {day }}{ }^{-1}$, $2.4 \mathrm{~cm} \mathrm{day}^{-1}$ and $2.4 \mathrm{~cm} \mathrm{day}^{-1}$, respectively.

Shoot and root dry matter weight reduced with water deficit (Tables 3 and 4, Figures 2 and 3), as observed by Pace et al. (1999). At 13 days after the water deficit imposing, these authors observed that the cotton tap root continued to grow under the stress condition, but reduced the growth of lateral or secondary roots. According to them, the tap root length was greater in the drought-treated plants than in the controls, and this response may allow cotton plants to survive drought by accessing water from deeper layers in the soil profile than with the levels provided during the periods of adequate water supply. However, 10 days after the resumption of normal irrigation and recovery of leaf turgor, droughttreated plants showed significantly smaller secondary root lengths and dry weight for the secondary and tap roots than the controls (without water stress).

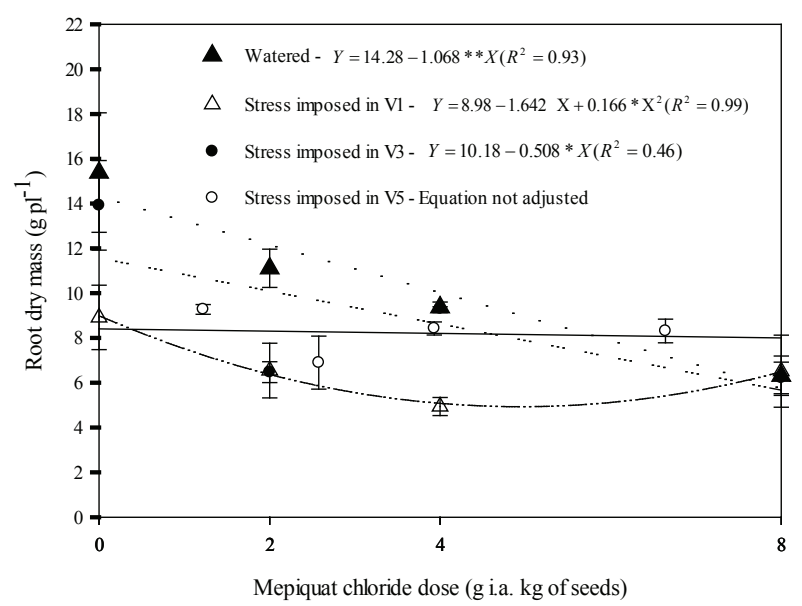

Figure 2. Root dry matter, according to mepiquat chloride used as seed treatment and water deficit - experiment 1.

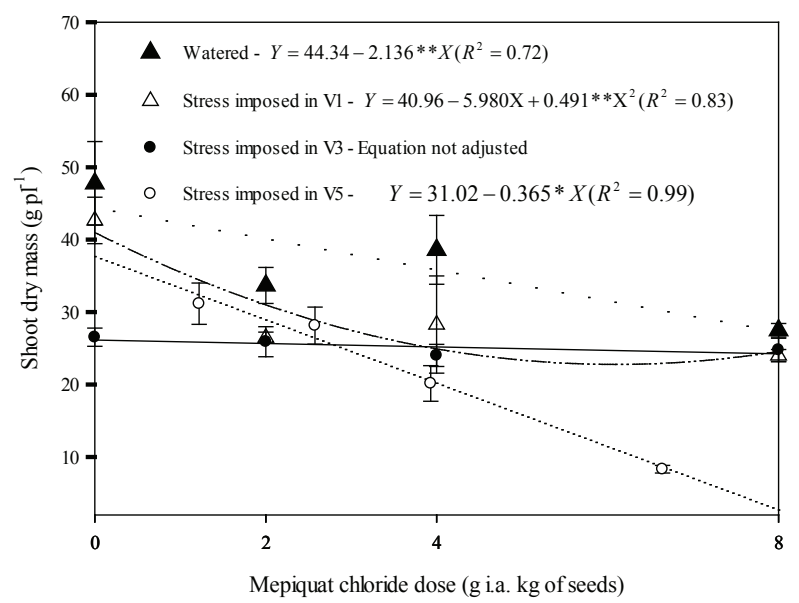

Figure 3. Shoot dry matter, according to mepiquat chloride used as seed treatment and water deficit - experiment 2. 
Shoot and root dry matter decreased by increasing the $\mathrm{MC}$ doses, in both experiments, and a significant interaction was observed between the MC doses applied by seed treatment and water deficit, for root dry matter, in the experiment 1 , and for shoot dry matter, in the experiment 2 (Figures 2 and 3). In both situations, the MC effect was potentized by water deficit. In a recent study, Almeida \& Rosolem (2012) observed that the application of MC to cotton seeds decreased shoot length, but had no significant effect on dry matter production, root length, shoot:root ratio or leaf area:root length ratio. However, Nagashima et al. (2011) concluded that cotton seeds treated with MC decreased shoot dry matter by $62 \%$, while the leaf area decreased $52 \%$.

Growth regulators promote changes in cotton shoot growth and may affect root development and increase the cotton plant sensitivity to water stress (Iqbal et al. 2005), being the same observed in this study. Even with the irrigation resumption, cotton plants did not recover their development to the same level of the control treatment, fact also noticed by Pace et al. (1999). Robertson et al. (2007) observed that the initial response of cotton plants under water deficit involves reduction in the rate of proliferation and cell expansion, resulting in reduced emissions of nodes and leaves. Concerning the results obtained in non-irrigated cotton production systems, in the Brazilian Savannah, caution is needed when recommending growth regulators for seeds treatment.

\section{CONCLUSIONS}

1. Shoot and root dry matter and cotton plant height decreased with increasing MC doses applied by seed treatment.

2. Water deficit in the initial vegetative development stage reduced shoot and root dry matter in cotton plant.

3. The inhibitory effects of MC applied via seeds on cotton growth and early development increased with water deficit.

\section{ACKNOWLEDGEMENTS}

To the Conselho Nacional de Desenvolvimento Científico e Tecnológico (CNPq), for the financial support, and to the Fundação Goiás, for the technical support.

\section{REFERENCES}

ALMEIDA, A. Q.; ROSOLEM, C. A. Cotton root and shoot growth as affected by application of mepiquat chloride to cotton seeds. Acta Scientiarum Agronomy, Maringá, v. 34, n. 1, p. 61-65, 2012.

BRITO, G. G. et al. Efeitos de 1-methylcyclopropeno e aminoethoxyvinylglycina sobre componentes de rendimento de algodoeiros crescidos sob condições de campo. Ciência e Agrotecnologia, Lavras, v. 37, n. 1, p. 9-16, 2013.

BRITO, G. G. et al. Physiological traits for drought phenotyping in cotton. Acta Scientiarum Agronomy, Maringá, v. 33, n. 1, p. 117-125, 2011.

EMPRESA BRASILEIRA DE PESQUISA AGROPECUÁRIA (Embrapa). Centro Nacional de Pesquisa de Solos. Manual de métodos de análises de solos. 2. ed. Rio de Janeiro: Embrapa, 1997.

IQBAL, M. et al. Contribution of mepiquat chloride in drought tolerance in cotton seedlings. Asian Journal of Plant Sciences, Bholakpur, v. 4, n. 5, p. 530-532, 2005.

LAMAS, F. M. Cloreto de mepiquat na cultura do algodoeiro via sementes. Dourados: Embrapa Agropecuária Oeste, 2006. (Boletim de pesquisa e desenvolvimento, 33).

LAMAS, F. M. Estudo comparativo entre cloreto de mepiquat e cloreto de chlormequat aplicados no algodoeiro. Pesquisa Agropecuária Brasileira, Brasília, DF, v. 36, n. 2, p. 265-272, 2001.

MARUR, C. J.; RUANO, O. A reference system for determination of cotton plant development. Revista de Oleaginosas e Fibrosas, Campina Grande, v. 5, n. 2, p. 243-247, 2001.

NAGASHIMA, G. T. et al. Desenvolvimento de plantas de algodão provenientes de sementes embebidas com cloreto de mepiquat. Pesquisa Agropecuária Brasileira, Brasília, DF, v. 40, n. 9, p. 943-946, 2005.

NAGASHIMA, G. T. et al. Embebição de sementes e aplicação foliar com cloreto de mepiquat no crescimento e produção do algodoeiro. Ciência e Agrotecnologia, Lavras, v. 31, n. 4, p. 1027-1034, 2007.

NAGASHIMA, G. T.; SANTOS, F. T.; MIGLIORANZA, E. Respostas de cultivares de algodão ao cloreto de mepiquat aplicado via embebição de sementes. Bragantia, Campinas, v. 70, n. 1, p. 46-49, 2011.

NICHOLS, S. P.; SNIPES, C. E.; JONES, M. A. Evaluation of row spacing and mepiquat chloride in cotton. Journal of Cotton Science, Baton Rouge, v. 7, n. 4, p. 148-155, 2003. 
OOSTERHUIS, D. Physiology and nutrition of high yielding cotton in the USA. Informações Agronômicas, Piracicaba, n. 95, p. 18-24, 2001.

PACE, P. F. et al. Drought-induced changes in shoot and root growth of young cotton plants. Journal of Cotton Science, Baton Rouge, v. 3, n. 4, p. 183-187, 1999.

RADEMACHER, W. Growth retardants: effects on gibberellin biosynthesis and other metabolic pathways. Annual Review of Plant Physiology, Palo Alto, v. 51, n. 1, p. 501-531, 2000.

REDDY, K. R.; REDDY, V. R.; HODGES, H. F. Temperature effects on early season cotton growth and development. Agronomy Journal, Madison, v. 84, n. 2, p. 229-237, 1992b.

REDDY, V. R.; TRENT, A.; ACOCK, B. Mepiquat chloride and irrigation versus cotton growth and development. Agronomy Journal, Madison, v. 84, n. 6, p. 930-933, 1992a.
ROBERTSON, B.; BEDNARZ, C.; BURMESTER, C. Growth and development: first 60 days. Cotton Physiology Today, Cordova, v. 13, n. 2, p. 1-5, 2007.

STEWART, A. M. et al. Wick applicator for applying mepiquat chloride on cotton: I. Rate response of wick spray delivery systems. Journal of Cotton Science, Madison, v. 5, n. 1, p. 9-14, 2001.

TAIZ, L.; ZEIGER, E. Plant physiology. 5th ed. Sunderland: Sinauer, 2010.

WELLS, R.; STEWART, A. M. Morphological alterations in response to management and environment. In: STEWART, J. M. et al. (Eds.). Physiology of cotton. London: Springer Dordrecht Heidelberg, 2010. p. 24-32.

YEATS, S. J.; CONSTABLE, G. A.; MCCUMSTIE, T. Cotton growth and yield after seed treatment with mepiquat chloride in the tropical winter season. Field Crops Research, Maryland Heights, v. 93, n. 2-3, p. 122131, 2005. 